\title{
The relative importance of the planktonic food web in the carbon cycle of an oligotrophic mountain lake in a poorly vegetated catchment (Redó, Pyrenees)
}

\author{
Lluís CAMARERO*, Marisol FELIP, Marc VENTURA, Frederic BARTUMEUS and Jordi CATALAN \\ Department of Ecology - Centre for High Mountain Research, University of Barcelona, Avd Diagonal 645, E-08028 Barcelona \\ *e-mail: camarero@porthos.bio.ub.es
}

\begin{abstract}
The biological activity of the planktonic community of lake Redó, expressed in terms of carbon fluxes, was measured and compared to the changes in DIC, DOC and POC in the water column. Planktonic photosynthesis ranged between c. $0.01-0.3 \mu \mathrm{g} C \mathrm{~m}^{-2}$ $h^{-1}$. Release of EOC phytoplankton was highly variable, between 5 and 80\% of total fixation. Bacterial uptake of EOC ranged between 1-20\% of total fixation. Bacterial activities were, in absolute numbers, very low: $0.005 \pm 0.003 \mu \mathrm{g} \mathrm{C} \mathrm{m} \mathrm{m}^{-2} \mathrm{~h}^{-1}$, in contrast with the higher grazing rates on bacteria of $0.036 \pm 0.021 \mu \mathrm{g} \mathrm{C} \mathrm{m} \mathrm{m}^{-2} \mathrm{~h}^{-1}$. Respiration and diffusion of $\mathrm{CO}_{2}$ to the atmosphere seem to be the main processes controlling DIC concentration. DOC and POC concentrations were highly correlated, and their fluxes presented large fluctuations. These changes in DOC are larger than those due to the processes we have measured. Other processes that might affect DOC include diffusion from sediments, inputs from the catchment, uptake by mixotrophic algae and zooplankton, bacterial respiration, UV photoxidation, and flocculation. Lake Redó seems to act in general terms as an heterotrophic system: respiration is higher than photosynthesis, and the budget is balanced by the import of DOC and, to a lesser extent, POC. Most of the carbon seems to be ultimately released to atmosphere, since little is accumulated in sediments. The estimates of diffusive fluxes agreed with this hypothesis. At this stage, the comparison of biogeochemical budgets with biological activity measurements only serves as a rough approximation of the main pathways in the C cycling in the lake, and to point the issues that need further research in order to calculate the $C$ budget in the lake with accuracy.
\end{abstract}

Key words: carbon fluxes, photosynthesis, respiration, bacterial activity, DIC, DOC, POC

\section{INTRODUCTION}

The biological activity in the pelagic systems of lakes shifts the equilibria of the different forms of carbon in the water by the fixation of inorganic carbon into organic carbon and its subsequent transformations along the food web. In addition to this, other processes (such as water-air exchange of $\mathrm{CO}_{2}$, decomposition of organic matter in sediments, sedimentation, or inputs from the catchment) play a role in the carbon budget of the lake. An appropriate way to discuss the importance of pelagic food webs in comparison to other processes regarding carbon fluxes, and to assess the relative weight of the internal autotrophic fixation versus the allochtonous input of carbon in the general metabolism of a lake, is to compare the observed changes in dissolved inorganic carbon (DIC), dissolved organic carbon (DOC), and particulate organic carbon (POC) in the water column to the expected effects of biological activities. This involves the use of two approaches: on the one hand, biogeochemical budgets derived from water chemistry monitoring and, on the other, discrete measurements of instantaneous rates of several biological activities. The time scales of these two measurements are different, and the exercise of fitting together all processes and comparing their magnitudes may reveal the problems of extending short time measurements to longer time scales, by showing the major features and trends in the cycling of carbon in the lake and the reliability (or lack of it) of the different estimates.

The aim of this work was to measure the biological activities affecting the different forms of carbon and the changes in the chemistry of these forms during the seasonal cycle in Lake Redó, in order to assess the relative weight of the carbon flow through the pelagic food web when compared to the general carbon cycle in the lake and the importance of internal production versus the import of organic carbon, to check the validity of combining both biological and biogeochemical approaches, and to identify potentially important processes to be considered in further studies.

\section{MATERIALS AND METHODS}

Lake Redó is located at $2240 \mathrm{~m}$ a.s.l. in the Central Pyrenees. It is deep (maximum depth is $73 \mathrm{~m}$, mean depth $32 \mathrm{~m}$ ) and relatively large (24 ha, representing $16 \%$ of the watershed area). The terrestrial part of the catchment has an area of 125 ha, and $25 \%$ consists of bare rock. The rest is covered by alpine meadows. Bedrock is granodiorite, with some intrusions of calcite. Soils are umbric-leptosol type, with an average depth of $35 \mathrm{~cm}$. Lake water is very dilute (mean conductivity = $11.5 \mu \mathrm{S} \mathrm{cm} \mathrm{cm}^{-1}$, total dissolved salts $=7 \mathrm{mg} \mathrm{l}^{-1}$ ), and slightly acidic (average $\mathrm{pH}=6.3$ ). The most abundant cation is $\mathrm{Ca}^{2+}\left(72 \mu \mathrm{eq}{ }^{-1}\right)$, being $\mathrm{HCO}_{3}^{-}\left(46 \mu \mathrm{eq} \mathrm{l}^{-1}\right)$ and $\mathrm{SO}_{4}{ }^{2-}\left(26 \mu \mathrm{eq} \mathrm{l}^{-1}\right)$ the dominant anions. The lake is oli- 
gotrophic: the average concentration of total phosphorus is $0.2 \mu \mathrm{mol} \mathrm{l}^{-1}$, and the soluble reactive fraction is generally lower than $0.01 \mu \mathrm{mol} \mathrm{l}^{-1}$. Among the nitrogen forms, $\mathrm{NO}_{3}^{-}$is relatively high $\left(11 \mu \mathrm{eq} \mathrm{l^{-1 }}\right)$, with lower concentrations of dissolved organic nitrogen $\left(4 \mu \mathrm{eq} \mathrm{l}^{-1}\right)$ and $\mathrm{NH}_{4}{ }^{+}\left(1 \mu \mathrm{eq} \mathrm{l}^{-1}\right)$. Further details on the main limnological features of Lake Redó can be found in Catalan (1988, 1989, 1992) and Catalan \& Camarero (1991, 1993). For a detailed description of physico-chemical conditions during the sampling period see Ventura et al. (1999).

Photosynthesis, bacterial activity and grazing on bacteria were measured during the ice free seasons of 1996 and 1997, according to the standardised protocols agreed within the MOLAR project. For details, see Wathne \& Hansen (1997) and Straškrabová et al. (1999, this issue). In 1996 these measurements were carried out during three field trips: June $28^{\text {th }}$, a short time after ice breaking: the water column was entirely mixed at 3.5 ${ }^{\circ} \mathrm{C}$, and light penetration was $10 \%$ of the surface irradiance at $25 \mathrm{~m}$ depth and $1 \%$ at $55 \mathrm{~m}$; July $4^{\text {th }}$ : water column still mixed at $5^{\circ} \mathrm{C}$, light penetration was $10 \%$ at 15 $\mathrm{m}$ and $1 \%$ at $40 \mathrm{~m}$; August $8^{\text {th }}-11^{\text {th }}$, when the lake was stratified, with a metalimnion from 5 to $15 \mathrm{~m}$ (temperature of $13-11^{\circ} \mathrm{C}$ in the epilimnion, $6-4{ }^{\circ} \mathrm{C}$ in the hypolimnion) and a light penetration of $10 \%$ at $25 \mathrm{~m}$ and $3 \%$ at the bottom. In 1997 the measurements were repeated on two occasions: August $1^{\text {st }}-5^{\text {th }}$, with a metalimnion between 6 and $27 \mathrm{~m}$ (epilimnion at $14{ }^{\circ} \mathrm{C}$ and hypolimnion at $5-4{ }^{\circ} \mathrm{C}$ ) and light penetration of $10 \%$ at $20 \mathrm{~m}$ and $1 \%$ at the bottom; September $2^{\text {nd }}-3^{\text {rd }}$, with the metalimnion from 13 to $27 \mathrm{~m}$ (epilimnion at 14-13 ${ }^{\circ} \mathrm{C}$, hypolimnion at $5-4{ }^{\circ} \mathrm{C}$ ) and light penetration of $10 \%$ at $20 \mathrm{~m}$ and $1 \%$ at $40 \mathrm{~m}$.

Photosynthesis was measured with the ${ }^{14} \mathrm{C}$ method. In 1996, only total particulate fixation was measured by collecting cells onto Whatman GF/F fiberglass filters, after incubating in situ $60 \mathrm{ml}$ water samples with added $\mathrm{NaH}^{14} \mathrm{CO}_{3}$ (c. $10 \mu \mathrm{Ci}$ per sample), for 2-3 h in quartzglass bottles. In $1997,{ }^{14} \mathrm{C}$ activities in the filtrate were also measured to estimate the fraction of extracellular organic carbon (EOC) released during incubations by purging the excess $\mathrm{NaH}^{14} \mathrm{CO}_{3}$ by acidifying with $\mathrm{HCl}$ and bubbling the samples, and particulate production was split into: a) phytoplankton carbon autotrophically fixed, this is, the fraction retained by Nucleopore polycarbonate filters of $1 \mu \mathrm{m}$ pore-size; and b) the part of EOC incorporated by bacteria, i. e., the cells smaller than $1 \mu \mathrm{m}$ from the previous filtrate which are retained in either Wathman GF/F or Nucleopore $0.2 \mu \mathrm{m}$ poresize filters. Practically identical results were obtained with both filters. Autotrophic picoplankton was very scarce in Lake Redó (Felip et al. 1999), and ${ }^{14} \mathrm{C}$ incorporation in this fraction may therefore be mainly attributed to bacteria. Radioassay was conducted in a Packard Tri-Carb 1500 liquid scintillation counter, using Biogreen 1 (Scharlau) scintillation cocktail.
To estimate the total photosynthetic carbon fixation into planktonic cells (particulate primary production), light saturation curves (or photosynthesis versus irradiance P-I curves) were constructed by incubating several water subsamples under a light gradient and determining photosynthesis at each light level by the ${ }^{14} \mathrm{C}$ method using Whatman GF/F filters (Camarero, in Wathne \& Hansen 1997). The resulting curves were fitted to a three-parameter equation, and particulate primary production was then estimated by using computer programs by Fee (1990) suitably modified to operate with the three-parameter photosynthesis model. The values of the photosynthetic parameters used to compute primary production throughout the year are the median of a number of data which were collected during several field studies conducted in different seasons, from the 1988 winter to the 1996 summer.

The model used to calculate particulate primary production was (Platt \& Gallegos 1980):

$$
P^{B}=P_{\max }^{B} \times\left(1-\exp \left(\frac{-\alpha^{B} I}{P_{\max }^{B}}\right)\right) \times \exp \left(\frac{-\beta^{B} I}{P_{\max }^{B}}\right)
$$

where photosyntesis $\left(P^{B}\right)$ is calculated as a function of irradiance $(I)$ using three parameters: the maximum potential photosynthetic rate $\left(P_{\max }^{B}\right)$, the slope of the light dependent segment of the curve $\left(\alpha^{B}\right)$, and the photoinhibition strength parameter $\left(\beta^{B}\right)$. The superscript $B$ indicates that the values are normalized by biomass, using chlorophyll- $a$ concentrations.

Bacterial activity was estimated using ${ }^{3} \mathrm{H}$-leucine incorporation rates (Kirchman 1993). One control and three replicate samples $(15 \mathrm{ml})$ were incubated with $25.5 \mathrm{nM}$ of ${ }^{3} \mathrm{H}$-leucine for c. 2 hours (incorporation stopped by adding formaldehyde to a final concentration of $2 \%$ ). For extraction, $2 \mathrm{ml}$ of $50 \%$ trichloroacetic acid (TCA) was added, and the mixture was heated to $85^{\circ} \mathrm{C}$ for $30 \mathrm{~min}$ and left at room temperature for $30 \mathrm{~min}$. Samples were then filtered through Nucleopore polycarbonate, $0.2 \mu \mathrm{m}$ pore-size filters presoaked in cold leucine; sample tubes were then rinsed in 5\% ice-cold TCA and the rinse was poured through the filter. Filters were subsequently rinsed twice with $5 \%$ TCA, once with $80 \%$ ethanol, and once with distilled water. Radioassay was as mentioned above. Leucine incorporation was converted into $\mathrm{C}$ units using the conversion factors proposed by Simon \& Azam (1989).

Grazing on bacteria was measured by the disappearance rate of fluorescently labelled bacteria (FLB): a known amount of FLB were added to 21 samples of lake water and samples incubated in situ. An initial 100 $\mathrm{ml}$ subsample for enumeration of total number of natural bacteria and FLB was taken just after addition of FLB, and then subsequently after 2, 8, 24 and 48 hours. Natural bacteria (using DAPI staining) and FLB number was determined by counting under epifluorescence microscope (Porter \& Feig 1980; Sherr \& Sherr 1993). 
Dissolved oxygen (1 $\mathrm{m}$ interval profiles), DIC, DOC and POC (3 $\mathrm{m}$ interval profiles) were measured monthly from June 1996 to July 1997. Dissolved oxygen in the water column was measured in situ using a WTW TA197 oxymeter. DIC and DOC were analysed in samples filtered through $\mathrm{GF} / \mathrm{F}$ fiberglass filters by using a Shimadzu TOC-5000 analyzer. Sestonic POC was measured by collecting the particles onto a pre-combusted $\mathrm{GF} / \mathrm{F}$ fiberglass filter (the sample was prefiltered through a nylon mesh to discard particles larger than $200 \mu \mathrm{m}$ ) and analysing the filters with a Carlo-Erba C$\mathrm{N}-\mathrm{H}-\mathrm{S}$ analyser. A similar procedure was used to measure particulate carbon collected in sediment traps deployed in the lake, but without excluding large particles. Inorganic carbon is unlikely to be present in the water column in particulate form, since carbonate concentration in water is far from the precipitation point, and mineral particles are scarce and predominantly siliceous. Thus we assumed the inorganic $\mathrm{C}$ fraction on filters analysed to be negligible. The carbon content in bulk sediment from a ${ }^{210} \mathrm{~Pb}$ dated core was determined using the same instrument. Particles larger than $200 \mu \mathrm{m}$ consisted almost exclusively of large zooplankton (copepodes and cladoceran). POC in this fraction was estimated by specimen enumeration and size measurement under the microscope, and by deriving carbon from biovolume using the appropriate conversion factors (Downing \& Rigler 1984). Oxygen, DIC, DOC and POC profiles were converted into per area units $\left(\mathrm{g} \mathrm{m}^{-2}\right)$ by calculating the corresponding lake average concentration $\left(\mathrm{g} \mathrm{m}^{-3}\right)$ weighted by the different water layer volumes according to the profile resolution, and multiplying it by the mean depth. DIC, DOC and POC concentrations were measured monthly at the outlet of the lake. Although water inflow is very irregular in space and time, water samples were taken during June, July and August 1997 in order to obtain an estimation of the characteristic chemistry during summer.

Hydrological and meteorological data used in primary production, $\mathrm{CO}_{2}$ air-water diffusive exchange, and water discharge calculations were obtained from an automatic weather station (AWS) located by the shore of the lake.

Inflow and outflow were estimated from precipitation data. There is a single outlet in Lake Redó. During the period of study outflow was measured occasionally; only during a short period of the ice-free season was water outflow monitored continuously. The very irregular inflow pattern prevented accurate measurement of inflow volume. Because of the lack of deep soils and the high mean slope of the catchment, we assumed a short retention time of precipitation water in the watershed during the ice-free season, and both the inflow and outflow be approximately the same, equal (on a monthly basis) to the precipitation volume minus a $10 \%$ loss due to evapotranspiration. This assumption is supported by the comparison of the short time series in which pre- cipitation and outflow were measured simultaneously during the ice free season: daily lake outflow closely followed the precipitation inputs. Average instantaneous outflow calculated in this way varied between $40-1001$ $\mathrm{s}^{-1}$, in the same range as the available measurements. During winter, outflow was much reduced and fairly constant, about $15 \mathrm{l} \mathrm{s}^{-1}$, while precipitation accumulated in the catchment as snow-cover. In consequence, monthly outflow during winter was calculated using this value of $15 \mathrm{l} \mathrm{s}^{-1}$, whereas during the thaw it was equalled to the precipitation accumulated during the winter months in form of snow, after subtracting the outflow calculated for winter. Melting of the snow cover thus resulted in a discharge peak of c. $2001 \mathrm{~s}^{-1}$ during thaw.

The diffusive flux of $\mathrm{CO}_{2}$ from water to air was calculated according to the equation:

$$
\text { Flux }=D_{G} \times\left(\left[\mathrm{C}-\mathrm{CO}_{2}\right]_{\mathrm{a}}-\left[\mathrm{C}-\mathrm{CO}_{2}\right]_{\mathrm{w}}\right) / \mathrm{z}
$$

where $D_{G}$ is the molecular diffusivity of $\mathrm{CO}_{2}$ in water, corrected for the water temperature (Broecker \& Peng 1982); $\left[\mathrm{C}-\mathrm{CO}_{2}\right]_{\mathrm{a}}$ is the carbon weight-to-volume concentration as $\mathrm{CO}_{2}$ in air, calculated as a function of atmospheric pressure at the lake altitude, air temperature, and a $\mathrm{CO}_{2}$ proportion in air of $0.036 \%$; $\left[\mathrm{C}-\mathrm{CO}_{2}\right]_{\mathrm{w}}$ is the carbon weight-to-volume concentration as $\mathrm{CO}_{2}$ in the upper $2 \mathrm{~m}$ water layer, calculated from the measured DIC using the equilibrium constants for the carbonate system corrected by water temperature and $\mathrm{pH}$ (Stumm \& Morgan 1981); and $\mathrm{z}$ is the stagnant film layer of water, estimated in $80 \mu \mathrm{m}$ corresponding to an average wind velocity of c. $4.5 \mathrm{~m} \mathrm{~s}^{-2}$ (Broecker \& Peng 1982).

\section{RESULTS}

\subsection{Photosynthesis}

The measurements of carbon fixation through photosynthesis are summarized in table 1. The absolute values of carbon fixed in the total particulate fraction were similar in both years, but showed differences in the vertical distribution of photosynthetic rates. The highest photosynthesis rates occurred deeper in 1996 than in 1997. In the uppermost layer (less than $10 \mathrm{~m}$ deep) photosynthesis was within the range of $0.05-0.15 \mu \mathrm{g} \mathrm{C}$ $\mathrm{l}^{-1} \mathrm{~h}^{-1}$ in both years. Maximum rates were recorded at an intermediate layer, (10-25 m) in 1997 and deeper in 1996 (30-35 m), with values ranging between 0.13 $0.28 \mu \mathrm{g} \mathrm{C}^{-1} \mathrm{~h}^{-1}$. In 1996, there was a low production layer between the surface one and the maximum, with values between $0.03-0.05 \mu \mathrm{g} \mathrm{C}^{-1} \mathrm{~h}^{-1}$. In contrast, photosynthesis was remarkably high at $55 \mathrm{~m}$ in 1996: the rates recorded were $0.10 \mu \mathrm{g} \mathrm{C}^{-1} \mathrm{~h}^{-1}$, whereas in 1997 they were less than $0.01 \mu \mathrm{g} \mathrm{C} \mathrm{l}^{-1} \mathrm{~h}^{-1}$.

The total amount of carbon released by phytoplankton (the dissolved EOC + the fraction uptaked by bacteria) during the incubations was much higher in August than in September 1997: in August it was about 45-80\% of total production, and the fraction incorporated by 
Tab. 1. Measurements of carbon fluxes through the pelagic microbial food web in Lake Redó during the ice free seasons of 1996 and 1997.

\begin{tabular}{|c|c|c|c|c|c|c|c|c|}
\hline \multirow[b]{2}{*}{ date } & \multirow[b]{2}{*}{$\begin{array}{l}\text { depth } \\
\text { (m) }\end{array}$} & \multicolumn{3}{|c|}{ C fixed through photosynthesis } & \multirow[b]{2}{*}{$\begin{array}{c}\text { EOC released by } \\
\text { phytopl. (dissol. } \\
\text { fraction) } \\
\left(\mu \mathrm{g} \mathrm{C}^{-1} \mathrm{~h}^{-1}\right)\end{array}$} & \multirow[b]{2}{*}{ 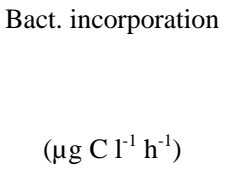 } & \multicolumn{2}{|l|}{ Grazing } \\
\hline & & $\begin{array}{c}(\mathrm{A})=\mathrm{C} \text { stored } \\
\text { into phytopl. } \\
\text { cells } \\
\left(\mu \mathrm{g} \mathrm{C}^{-1} \mathrm{~h}^{-1}\right)\end{array}$ & $\begin{array}{c}(\mathrm{B})=\mathrm{C} \text { stored in } \\
\text { bacteria (EOC in } \\
\text { partic. fraction) } \\
\left(\mu \mathrm{g} \mathrm{C}^{-1} \mathrm{~h}^{-1}\right)\end{array}$ & $\begin{array}{c}\text { Total particulate } \\
\qquad(\mathrm{A}+\mathrm{B}) \\
\left(\mu \mathrm{g} \mathrm{Cl}^{-1} \mathrm{~h}^{-1}\right)\end{array}$ & & & \multicolumn{2}{|c|}{$\left(\mu \mathrm{gCl}^{-1} \mathrm{~h}^{-1}\right)$} \\
\hline \multirow[t]{2}{*}{28 June 96} & 1 & & & 0.056 & & 0.0023 & & \\
\hline & 30 & & & 0.246 & & 0.0043 & & \\
\hline \multirow[t]{2}{*}{4 July 96} & 1 & & & 0.093 & & 0.0045 & & \\
\hline & 30 & & & 0.190 & & 0.0052 & & \\
\hline \multirow[t]{5}{*}{8 August 96} & 2 & & & 0.087 & & 0.0051 & 0.0354 & 8-10 Aug \\
\hline & 9 & & & 0.033 & & n.d. & 0.0067 & \\
\hline & 18 & & & 0.027 & & 0.0033 & 0.0393 & \\
\hline & 35 & & & 0.195 & & 0.0019 & 0.0250 & \\
\hline & 55 & & & 0.105 & & 0.0060 & 0.0775 & \\
\hline \multirow[t]{2}{*}{10 August 96} & 1 & & & 0.049 & & 0.0042 & & \\
\hline & 30 & & & 0.172 & & 0.0040 & & \\
\hline \multirow[t]{5}{*}{11 August 96} & 2 & & & 0.102 & & 0.0050 & & \\
\hline & 9 & & & 0.046 & & 0.0018 & & \\
\hline & 18 & & & 0.025 & & 0.0044 & & \\
\hline & 35 & & & 0.280 & & 0.0035 & & \\
\hline & 55 & & & 0.098 & & 0.0099 & & \\
\hline \multirow[t]{2}{*}{1 August 97} & 2 & 0.033 & 0.037 & 0.070 & 0.095 & 0.0026 & & \\
\hline & 25 & 0.123 & 0.027 & 0.150 & 0.097 & 0.0036 & & \\
\hline \multirow[t]{5}{*}{5 August 97} & 2 & & & & & 0.0047 & 0.0244 & 5-7 Aug \\
\hline & 9 & 0.124 & 0.026 & 0.150 & 0.393 & 0.0065 & 0.0397 & \\
\hline & 18 & & & & & 0.0037 & 0.0660 & \\
\hline & 35 & & & & & 0.0009 & 0.0671 & \\
\hline & 55 & 0.005 & 0.005 & 0.010 & 0.003 & 0.0077 & 0.0348 & \\
\hline \multirow[t]{5}{*}{2 September 1997} & 2 & 0.086 & 0.002 & 0.088 & 0.005 & 0.0076 & n.d. & 2-4 Sep \\
\hline & 9 & 0.127 & 0.005 & 0.132 & 0.019 & 0.0080 & 0.0151 & \\
\hline & 18 & 0.089 & 0.003 & 0.092 & 0.017 & 0.0105 & 0.0300 & \\
\hline & 35 & 0.041 & 0.005 & 0.046 & 0.008 & 0.0113 & 0.0282 & \\
\hline & 55 & 0.005 & n.d. & 0.005 & n.d. & 0.0033 & 0.0208 & \\
\hline \multirow[t]{5}{*}{3 September 1997} & 2 & 0.038 & 0.001 & 0.039 & n.d. & 0.0042 & & \\
\hline & 9 & 0.037 & 0.001 & 0.038 & 0.005 & 0.0032 & & \\
\hline & 18 & 0.263 & 0.011 & 0.274 & 0.016 & 0.0085 & & \\
\hline & 35 & 0.063 & 0.003 & 0.066 & 0.013 & 0.0041 & & \\
\hline & 55 & 0.007 & n.d. & 0.007 & n.d. & 0.0020 & & \\
\hline
\end{tabular}

bacteria was $5-20 \%$ of total fixation (particulate + dissolved). In September the total released carbon was 5$20 \%$, and bacterial uptake $1-5 \%$ of total fixation.

The parameters used in estimating phytoplankton primary production are shown in table 2 , grouped according characteristic productive stages and taking into account differences with depth, as described in the table. Estimates of particulate primary production based on measured irradiance at the lake surface, and light extintion and chl- $a$ in the water column are shown as a part of figures 3 and 5 and discussed below.

\subsection{Bacterial carbon incorporation}

Estimates of carbon incorporation by bacteria from ${ }^{3} \mathrm{H}$-leucine uptake (expressed in $\mathrm{C}$ units using conver- sion factors) in Lake Redó are shown in table 1. They were very low, often close to the detection limit of the method, and do not exhibit any clear spatial or seasonal trend. The most usual values range between 0.004 $0.011 \mu \mathrm{g} \mathrm{C}^{-1} \mathrm{~h}^{-1}$ (mean $\pm 1 \mathrm{SD}=0.005 \pm 0.003 \mu \mathrm{g} \mathrm{Cl}^{-1}$ $\mathrm{h}^{-1}$ ). Though slightly higher, these figures are in agreement with the estimates of bacterial $\mathrm{C}$ uptake derived from the photosynthesis measurements, but only when the release of EOC by phytoplankton is low. When EOC was high, bacterial carbon fixation estimated with ${ }^{14} \mathrm{C}$ was one order of magnitude higher than that obtained with ${ }^{3} \mathrm{H}$. A hypothetical explanation is that bacteria incorporate phytoplankton exudates preferentially, and that leucine incubations might yield an underestimation of bacterial activity when these exudates are a signifi- 
Tab. 2. Typical values of the photosynthetic parametres of the phytoplankton communities in Lake Redó for the different seasons and depths.

\begin{tabular}{|c|c|c|c|c|c|c|c|c|c|c|}
\hline \multirow[b]{2}{*}{ Period description } & \multirow[t]{2}{*}{$\begin{array}{l}\text { depth } \\
(\mathrm{m})\end{array}$} & \multicolumn{3}{|c|}{$\alpha^{\mathrm{B}}$} & \multicolumn{3}{|c|}{$\beta^{\mathrm{B}}$} & \multicolumn{3}{|c|}{$\mathrm{P}_{\text {max }}^{\mathrm{B}}$} \\
\hline & & median & $\max$ & $\min$ & median & $\max$ & $\min$ & median & $\max$ & $\min$ \\
\hline First stage of the ice cover (January) & $0-40$ & 1.81 & 3.56 & 0.92 & 0.056 & 0.092 & 0.000 & 0.35 & 0.45 & 0.26 \\
\hline Transition towards low 1 & $40-73$ & 5.14 & 6.00 & 4.44 & 0.117 & 0.156 & 0.081 & 0.45 & 0.5 & 0.35 \\
\hline Mid winter (February-March) & $0-40$ & 4.97 & 7.53 & 1.92 & 0.050 & 0.250 & 0.000 & 1.16 & 1.48 & 0.71 \\
\hline it regime & $40-73$ & 33.64 & & & 0.442 & & & 5.46 & & \\
\hline End of winter & $0-40$ & 0.50 & 0.75 & 0.08 & 0.000 & 0.000 & 0.000 & 0.04 & 0.1 & 0.02 \\
\hline Decaying populations, low production & $40-73$ & 1.39 & & & 0.017 & & & 0.17 & & \\
\hline Spring overturn - summer (June-October) & $0-2$ & 2.50 & 3.89 & 1.11 & 0.131 & 1.653 & 0.108 & 0.43 & 2.01 & 0.32 \\
\hline Highe & $2-30$ & 0.8 & 43.89 & 0.08 & 0.03 & 0.036 & 0.025 & 0.0 & 0.1 & 0.02 \\
\hline deep $\mathrm{cl}$ & $30-73$ & 4.44 & 8.33 & 1.39 & 0.264 & 1.078 & 0.144 & 0.31 & 1.05 & 0.2 \\
\hline $\begin{array}{l}\text { Fall overturn (November-first half December). End } \\
\text { of the productive season }\end{array}$ & $0-73$ & 2.58 & 11.42 & 1.17 & 0.031 & 0.078 & 0.007 & 0.19 & 0.53 & 0.07 \\
\hline Ice cover forming (second $\mathrm{h}$ & & & & 1.1 & & 0.028 & 0.003 & & 0.12 & 0.04 \\
\hline Sudden change in exposure light, first adaptation & $15-73$ & 4.83 & 7.31 & 3.14 & 0.144 & 0.219 & 0.075 & 0.59 & 0.79 & 0.41 \\
\hline
\end{tabular}

cant fraction of the DOC. Bacterial activity in the water column (measured using the ${ }^{3} \mathrm{H}$-leucine method) was similar all year round, as indicated by measurements made during the season of ice cover (M. Felip, unpub. data).

\subsection{Grazing on bacteria}

The results on the consumption of bacteria are displayed in table 1 . These results are difficult to extrapolate to the natural conditions, because the estimated grazing rates (range $=0.007-0.070 \mu \mathrm{g} \mathrm{C} \mathrm{l}^{-1} \mathrm{~h}^{-1}$; mean $=$ $0.036 \pm 0.021 \mu \mathrm{g} \mathrm{C}^{-1} \mathrm{~h}^{-1}$ ) are about one order of magnitude higher than the bacterial production, meaning that bacteria cannot sustain the grazer population in the long run. In consequence, the grazing rates we have measured should be considered as a maximum or potential grazing activity which can proceed only during limited periods.

\subsection{Seasonal evolution of DIC, DOC and POC}

The seasonal changes in the water column concentration of DIC, DOC and POC are shown in figure 1. The main $\mathrm{C}$ pools in the lakewater were DOC (annual average $\left.=40 \mathrm{~g} \mathrm{C} \mathrm{m}^{-2}\right)$ and DIC $\left(30 \mathrm{~g} \mathrm{C} \mathrm{m}^{-2}\right)$, which were one order of magnitude larger than POC (4 g C $\mathrm{m}^{-2}$ ). Three periods may be distinguished during the year: 1) A period corresponding to the formation and destruction of the summer thermal stratification, from July to November, with the complete mixing of the water column taking place in late November. The highest concentrations and sharper fluctuations of all three forms of carbon occurred during this period; 2) Period of ice cover, from mid December to early May. During the first half of this period (until mid February), DOC and POC remained rather constant, while DIC increased progressively. During the second half all three forms decreased. 3) During the spring overturn, DOC and POC started to rise again just after the ice breaking. In contrast, DIC continued to decrease, only recovering slightly during the last month. Despite the difference in their magnitudes, DOC and POC exhibited remarkably parallel evolution during the year, as shown by the high correlation between the two forms of carbon (Fig. 2).

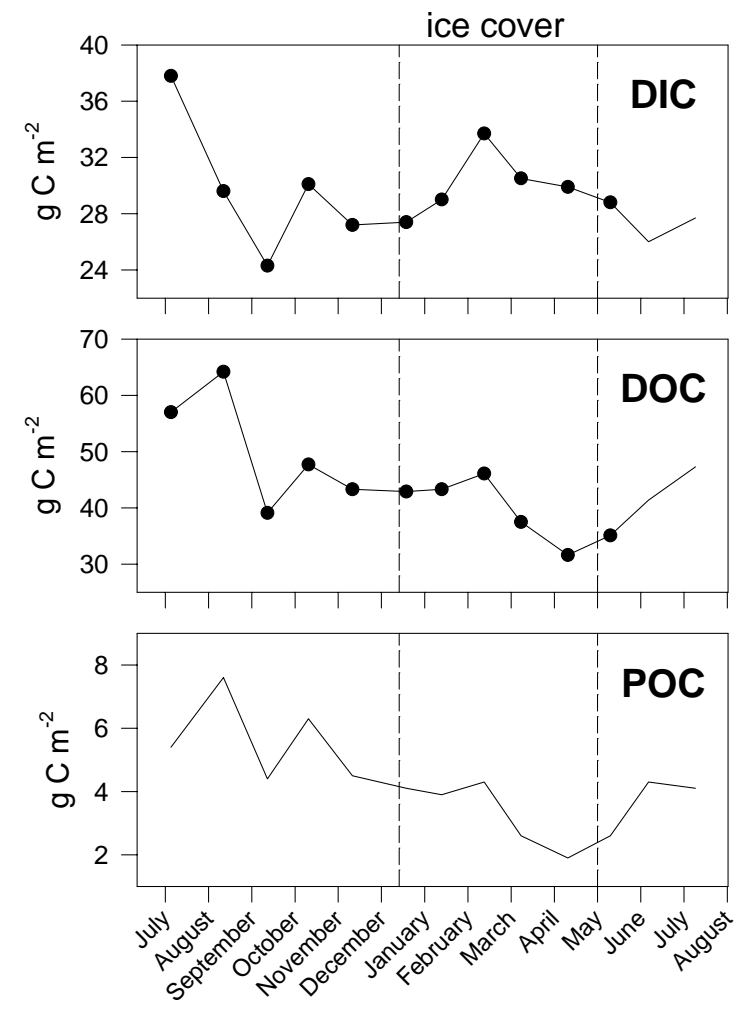

Fig. 1. Seasonal evolution of DIC, DOC and POC in the water column of Lake Redó

\section{DISCUSSION}

To discuss all these results, we will compare the changes observed in carbon content in the water column versus the fluxes derived from the processes measured. Figures 3 to 5 show the fluxes of the different forms of 
carbon estimated from the field measurements. The black bars represent the increments calculated by difference between two consecutive, monthly-spaced measurements of the concentration in the water column. Negative increments mean a loss of carbon from the water column. The monthly fluxes as estimated from the different processes measured are represented in a single, cumulative bar using different fill patterns, and displayed beside the corresponding black bars representing the increments observed. The difference between both bars are the flux that remains to be explained, either by processes other than those measured in this study or by possible inaccuracies in the method adopted.

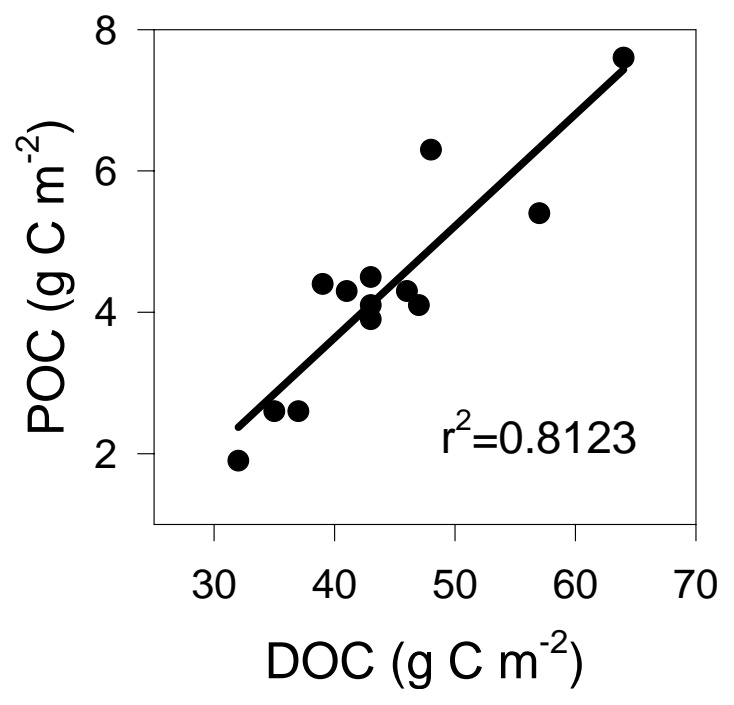

Fig. 2. Relationship between DOC and POC in Lake Redó.

\subsection{DIC}

Calculated fluxes of DIC are shown in figure 3. The fluxes that can be estimated from the available measurements are photosynthetic uptake (including both particulate phytoplankton plus bacterial uptake and exudates), diffusion of $\mathrm{CO}_{2}$ to the atmosphere and export through the outflow. From these results, the highest loss of DIC from the water column is the diffusion of $\mathrm{CO}_{2}$, except for the months in which the lake is frozen and gas exchange is prevented. Carbon uptake by photosynthesis had a lesser effect, and was always less than one half of the diffusive flux, and less than one fourth in most cases. Export of DIC through the outflow was also low compared to the total. It was of the same order as photosynthesis during the periods with a higher water flow (springtime melting and December) and lower during the rest of the ice-free period. Except in the period from February to April, the sinks of DIC were larger than the actual decrease, indicating that the sources of DIC needed to complete the budget are not sufficient. The most probable sources are respiration and import through the inlets.

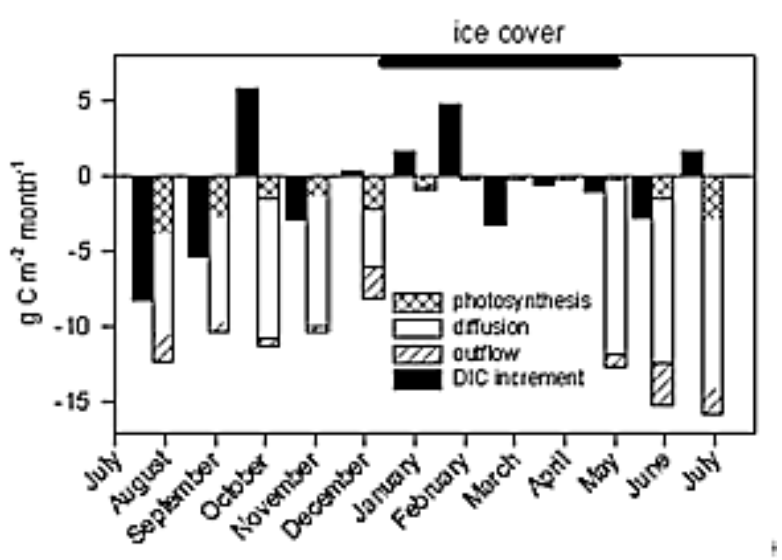

Fig. 3. Measured monthly increments of DIC (black bars) in Lake Redó, and estimated fluxes of $\mathrm{C}$ through the different processes considered (shaded bars), from July 1996 to August 1997. Each adjacent pair (black and shaded) of bars represent the changes between two samplings. The midpoints between each pair of bars correspond to the sampling dates.

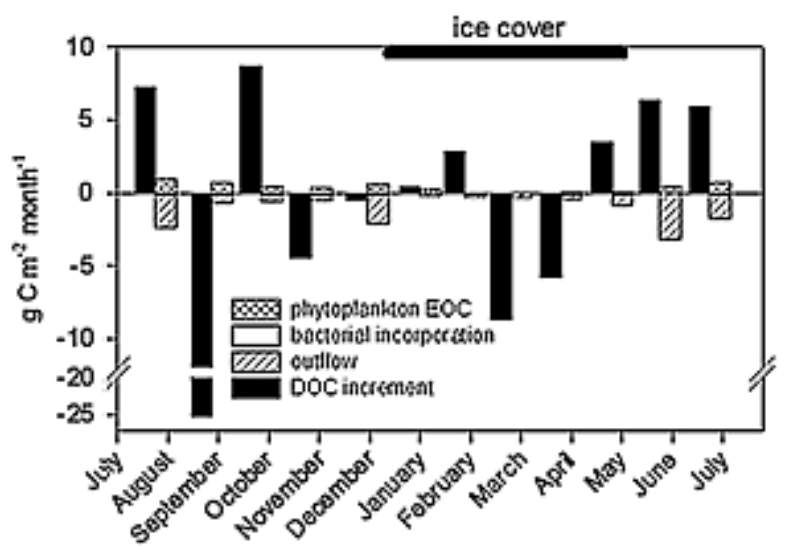

Fig. 4. As figure 3 but for DOC.

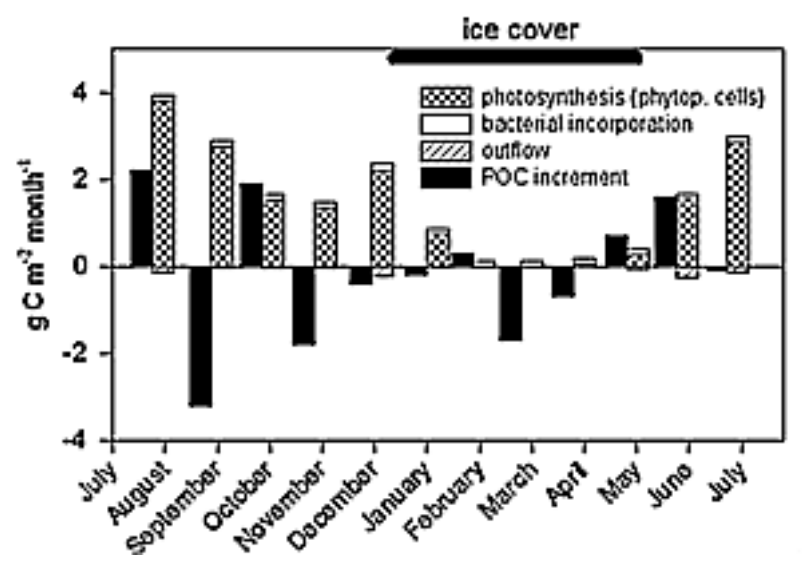

Fig. 5. As figure 3 but for POC.

DIC concentration at the inlets may be estimated from the surface alkalinity and $\mathrm{pH}$ values, assuming the surface running water entering the lake is in equilibrium with atmospheric $\mathrm{CO}_{2}$. Although carbonate and bicar- 
bonate concentrations are similar, lake water is oversaturated in $\mathrm{CO}_{2}$, causing the export of $\mathrm{C}$ to be slightly higher than import. However, both fluxes had a relatively low magnitude compared with the overall DIC budget, owing to the small water throughflow compared to the lake volume. Because of this, and the fact that DIC concentration was similar in both inflow and outflow, we may assume that they roughly balance.

Total respiration (that is, respiration in both the water column and sediments) estimates from oxygen profile measurements can only be calculated during winter, when the lake can be considered as being isolated from the atmosphere by the ice cover and photosyntesis is practically null because of the lack of light. From the oxygen profiles measured during the winter (January to April) of the study period, we estimated an oxygen consumption of $10 \mathrm{~g} \mathrm{O}_{2} \mathrm{~m}^{-2}$ month $^{-1}$, or an equivalent production of $\mathrm{CO}_{2}$ of c. $3.4 \mathrm{~g} \mathrm{C} \mathrm{m}^{-2}$ month $^{-1}$ as DIC, comparable to the 2.4 (December-January) and 4.7 (January-February) $\mathrm{g} \mathrm{C} \mathrm{m}^{-2} \mathrm{month}^{-1}$ resulting from the DIC budget (observed DIC increment minus photosynthesis and diffusion). Surprisingly, DIC increments were negative from February to April. If we accept a constant respiration rate for the whole winter, then a certain permeability of the ice cover during the second half of winter must be assumed, allowing a diffusion of $\mathrm{CO}_{2}$ of c. $20-30 \%$ of the flux without ice cover.

From the DIC budget results, respiration seems to be higher during the ice-free period, with values ranging between 3 and $17 \mathrm{~g} \mathrm{C} \mathrm{m}^{-2} \mathrm{~d}^{-1}$ (mean $\pm \mathrm{SD}=9 \pm 5 \mathrm{~g} \mathrm{C}$ $\left.\mathrm{m}^{-2} \mathrm{~d}^{-1}\right)$. This change in respiration rates might be consistent with some observations: although respiration rates seemed to be constant during the 1996-97 winter, during the very early ice-covered period we measured oxygen consumption rates up to 15 (1984-85, Catalan 1992) and 27 (1997-98, M. Ventura unpub. data) g $\mathrm{O}_{2}$ $\mathrm{m}^{-2}$ month ${ }^{-1}$, or an equivalent production of $\mathrm{CO}_{2}$ of c. 5 and $9 \mathrm{~g} \mathrm{C} \mathrm{m}^{-2}$ month $^{-1}$ respectively, and then decreases down to $6 \mathrm{~g} \mathrm{O}_{2} \mathrm{~m}^{-2} \mathrm{~d}^{-1}$, or c. $2 \mathrm{~g} \mathrm{C} \mathrm{m}^{-2} \mathrm{~d}^{-1}$ in both years, as the oxygen availability and the number of organisms fell in mid-winter.

It has to be noted that the computation of $\mathrm{CO}_{2}$ diffusive fluxes are very sensitive to the value of $z$, the thickness of the stagnant film layer in equation 2. $z$ strongly depends on the wind velocity. This relationship is not linear, but $z$ increases exponentially with decreasing wind speed. Thus, the averaging of wind speed during long periods may be misleading, in the sense that it tends to yield underestimates of $z$, and as such it is the main source of uncertainity in estimating $\mathrm{CO}_{2}$ diffusion across the water-air interface. The assignment of an average $z=80 \mu \mathrm{m}$ (corresponding to a wind speed of 4.5 $\mathrm{m} \mathrm{s}^{-1}$ ) seems to be in good agreement with the observed respiration rates, but a choice of a similar wind speed of $5 \mathrm{~m} \mathrm{~s}^{-1}$, for instance, would lead to an estimation of $\mathrm{CO}_{2}$ fluxes that are almost two-fold higher. This uncertainity in computing $\mathrm{CO}_{2}$ diffusion means that a respiration- diffusion (which seem to be the main process affecting the DIC budget) balance may be adjusted only to the order of magnitude level.

Another uncertainity is the effect of benthic photosynthesis. We have no measurements of this but, although scarce (the lake has no macrophytes, just a few mosses in the littoral zone; the rest are microalgae living on the surface of stones and sediments) these benthic communities could be a significant sink of $\mathrm{CO}_{2}$. Part of the estimated DIC decrease attributed to $\mathrm{CO}_{2}$ diffusion might therefore be caused by benthic photosynthesis. Nevertheless, this probably only has a small effect on the overall $\mathrm{C}$ cycle, because the standing biomass of the algal film on rocks is low, and soft sediments do not seem to be a store for this extra production (see below). Therefore, either benthic photosynthesis is very low, or most of $\mathrm{C}$ fixed through it is respired and, finally, released to the atmosphere.

\subsection{DOC and POC}

Given the similarity of the changes in their fluxes, we will discuss the evolution of DOC and POC jointly. Fluxes of DOC and POC are represented in figures 4 and 5, respectively. Bacterial incorporation in both graphs refers to ${ }^{3} \mathrm{H}$-leucine measurements. Photosynthesis in the POC budget consists only of the fraction incorporated by phytoplankton cells. During the first months before the ice cover forms, fluctuations in the net fluxes (black bars) of both DOC and POC are very strong. Periods of elevated inputs are apparently followed by phases of rapid consumption. Afterwards, below the ice cover, there were two months with little change but a slight increase in February. In the case of POC, this increase is due to a blooming of Daphnia pulicaria (their biomass rose up to $1.5 \mathrm{~g} \mathrm{C} \mathrm{m}^{-2}$ ), in contrast with a decrease in the particles smaller than $200 \mu \mathrm{m}$. This peak is also present in the case of DIC and DOC, suggesting that the change in both forms of dissolved carbon also reflect the metabolism of the large D. pulicaria population. During February and March, increments of POC and DOC were negative, until the onset of the ablation of the ice cover in the lake and the snow cover in the watershed in April, when they became positive. It was only in the last month (June) when fluxes of DOC and POC differed: DOC increased while POC decreased slightly.

These fluxes of DOC derived from the content budget cannot be explained by the processes we have measured: phytoplankton exudation, bacterial incorporation $\left({ }^{3} \mathrm{H}\right.$-leucine measurements) and export through the outflow are of a much lower magnitude than the changes we observed. We can only hypothesize as to what might be the possible sources and sinks of DOC in the water column. As for the positive fluxes, it seems that they might originate from an external source: either the sediments or the catchment. In contrast, the parallel increases in POC are of the same magnitude as those of 
C fixation into phytoplankton cells by photosynthesis; nevertheless, this photosynthetic uptake is derived from short time incubations with ${ }^{14} \mathrm{C}$-bicarbonate and it should therefore be close to a gross uptake estimation, from which respiration should be subtracted to calculate the net flux into cells. Given that respiration rate guesses are 2 to 5 times greater than photosynthetic rates (Fig. 3), and considering the coincidence in DOC and POC changes, it seems reasonable to think that external inputs of POC also play a role.

There is evidence from sediment trap studies that particle resuspension from sediments occurs during the overturn periods: abundant frustules of benthic diatoms were found even in the most surficial traps during these periods (S. Pla, unpub. data). Diatoms associated to rocks in the littoral zones appeared during the thaw, probably resuspended by the mechanical action of breaking ice in the shores, while diatoms associated to soft sediments appeared in the autumn overturn when the mixed layer reached the $40 \mathrm{~m}$ depth limit. Resuspension of POC could be accompanied by turbulent diffusion of DOC from sediment porewater. Alternatively, it could be that the DOC rise during the thaw and postthaw months (April to July) was due to inputs from the catchment associated with melting snow intrusion: an average concentration of DOC in the inflow water during these months of 4-7 $\mathrm{mg} \mathrm{l}^{-1}$ would be enough to account for the increase, whereas a few measurements (DOC in precipitation was not continuously monitored) indicated that typical values in precipitation are in the range of 2-10 $\mathrm{mg} \mathrm{l}^{-1}$, making theoretically possible an increased inflow of DOC coming from the accumulated precipitation in the form of snow. The input that occurred in October is more difficult to explain: owing to the reduced water inflow, a concentration of $20 \mathrm{mg} \mathrm{l}^{-1}$ of DOC in the water entering the lake would be required to account for the rise in the water column. Excretion of DOC during feeding by micro- (Strom et al. 1997; Jumars et al. 1989) and macrozooplancton (Lampert 1978) might be another source of DOC, but it would be still a fraction of photosynthesis, which can not account for the large increases observed.

The negative fluxes of DOC are much higher than the export through the outflow and than any bacterial activity we have measured. Other possible sinks of DOC could be the formation of aggregates of organic matter and subsequent sedimentation (Alldredge \& Jackson 1995), photo-oxidation of organic molecules by UV radiation (Bushaw et al. 1996; Granéli et al. 1996), and uptake by mixotrophic algae (Sibbald \& Albright 1991; Holen \& Boraas 1995) and zooplankton (Jumars et al. 1989). It might also be the case that bacterial respiration was much higher than the carbon fixed in the cell bodies and the real DOC consumption by bacteria was thus higher than that estimated by incorporation only.
Independently of the way in which DOC is removed from the water column, the fate of this carbon seems to be oxidation to $\mathrm{CO}_{2}$ and release to the atmosphere because of the following two reasons.

1) Sedimentation rates and accumulation in sediments are much lower than DOC and POC decreases, indicating that storage in sediments cannot account for all sinks: the sediment traps yield sedimentation rates ranging between $0.08 \mathrm{~g} \mathrm{C} \mathrm{m}^{-2}$ month $^{-1}$ at the end of the winter and $0.57 \mathrm{~g} \mathrm{C} \mathrm{m}^{-2}$ month $^{-1}$ during the ice breaking. Accurate inventories of carbon in sediments are difficult to obtain, because of the horizontal heterogeneity of the sediment accumulation. Analyses of certain sediment cores gave somewhat lower values $\left(0.08-0.15 \mathrm{~g} \mathrm{C} \mathrm{m}^{-2}\right.$ month $^{-1}$, obtained from annual estimates for the last 80 years) but within the same range as those obtained from the sediment traps. Nonetheless, other cores exhibited sedimentation rates (in $\mathrm{mm} \mathrm{y}^{-1}$ ) that were ten times higher and, although carbon analyses are not available for these cores, the organic content as induced from loss on ignition measurements was comparable (S. Pla, pers. comm.). On the other hand, results from the analysis of bathymetric maps of the lake suggest that the bottom area is suitable for sediment accumulation (slope lower than 14\%, Håkanson 1981) as c. only $10 \%$ of the total area and $50 \%$ of the lake has slopes steeper than $50 \%$. Thus, the apparent accumulation rates are higher than the real sedimentary fluxes because of focussing in the deepest areas. Ignoring this, and assuming that the deposition area was $100 \%$ of the lake area, and that carbon sedimentation rates ranged between one- and tenfold the average for the last 80 years in the sediment cores for which carbon analyses are available, the sedimented carbon would be between c. 2 and $13 \mathrm{~g} \mathrm{C} \mathrm{m}^{-2}$ $\mathrm{y}^{-1}$. These overestimates are still clearly lower than the sum of negative fluxes of both DOC and POC (once corrected by the estimated outflow, photosynthesis, EOC release and bacterial activity) estimated in $63 \mathrm{~g} \mathrm{C}$ $\mathrm{m}^{-2} \mathrm{y}^{-1}\left(44 \mathrm{~g} \mathrm{~m}^{-2}\right.$ of DOC and $19 \mathrm{~g} \mathrm{~m}^{-2}$ of POC). Therefore, between c. 50 and $60 \mathrm{~g} \mathrm{C} \mathrm{m}^{-2}$ in the form of DOC and POC disappeared per year from the water column and in all likelihood was not stored in sediments.

2) According to our estimates, photosynthesis is much lower than respiration in the lake, even if possible losses of photosynthetic carbon are ignored, which means that the largest fraction of the substract for respiration should consist of allochthonous carbon not photosynthetically fixed: the carbon fixed into POC through photosynthesis during the whole year would be $17 \mathrm{~g} \mathrm{C}$ $\mathrm{m}^{-2} \mathrm{y}^{-1}$, while respiration would be $89 \mathrm{~g} \mathrm{C} \mathrm{m}^{-2} \mathrm{y}^{-1}$. At least the difference, $72 \mathrm{~g} \mathrm{C} \mathrm{m}^{-2} \mathrm{y}^{-1}$, must have an allochthonous origin. This amount could be accounted for by the DOC lost from the water column, although the estimated $44 \mathrm{~g} \mathrm{C} \mathrm{m}^{-2} \mathrm{y}^{-1}$ is lower than the $72 \mathrm{~g} \mathrm{C} \mathrm{m}^{-2} \mathrm{y}^{-1}$ needed to complete the balance. Uncertainity in estimating $\mathrm{CO}_{2}$ diffusion, as discussed above, which has a strong effect on our respiration estimates may account 
for this discrepancy. Taking $z=110 \mu \mathrm{m}$ which corresponds to a wind speed of $4 \mathrm{~m} \mathrm{~s}^{-1}$, instead of $4.5 \mathrm{~m} \mathrm{~s}^{-1}$, would give a respiration rate of $67 \mathrm{~g} \mathrm{C} \mathrm{m}^{-2} \mathrm{y}^{-1}$, and a corresponding allochthonous respiration of $50 \mathrm{~g} \mathrm{C} \mathrm{m}^{-2} \mathrm{y}$ ${ }^{1}$, which is much closer to the hypothetical DOC contribution. Another explanation might be the decomposition and respiration of carbon in older strata of the sediment. However, this is more unlikely, because old carbon usually consists of the most refractory forms.

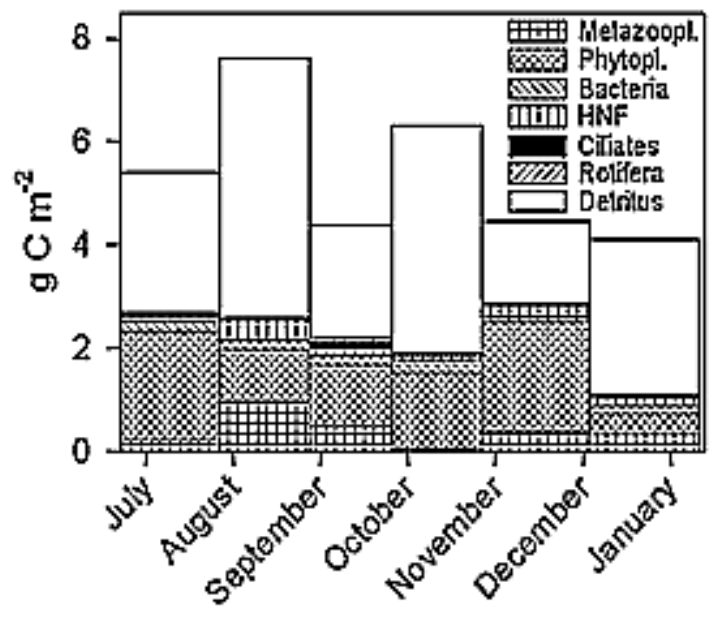

Fig. 6. Concentration of the different fractions of POC during the ice free season of 1996 in Lake Redó.

Although, for the reasons exposed above, the formation of aggregates of DOC and their deposition in sediments does not seem to be a significant way of taking carbon out of the lake, this mechanism might play a role in the internal cycling of $\mathrm{C}$. Thus, if we look at the fractions of POC during the ice-free season (Fig. 6), more than half the POC consists of amorphous, dead organic matter. Carbon content in organisms was estimated by cell counting and application of the appropriate conversion factors (Felip et al. 1999, this issue), and subtracted from the results of the analyses of sestonic carbon collected onto filters to estimate the detrital fraction. While living organisms maintain a largely constant biomass, changes in the detrital fraction followed the strong fluctuations of DOC, suggesting that this could be the link that explains the close relationship between the two forms of carbon. Another possible explanation is that this particulate detrital carbon was mainly allochthonous and entered the lake accompanied by DOC, but then the parallel disappearance remains to be explained. If aggregation of DOC has a significant effect, DOC could be transported in this way to deeper layers or to the sediment surface, and this would help to explain the high rates of DOC depletion after the large inputs. Most of this DOC might be respired there or eventually resuspended during the overturn and consumed in the water column, since there was no evidence of carbon accumulation in the upper layers of sediments, as discussed above.

\section{CONCLUSION}

The biological activity of the planktonic community of Lake Redó, expressed in terms of carbon fluxes, was measured and compared to changes in DIC, DOC and POC in the water column.

Planktonic photosynthesis (particulate production) during the ice-free period ranged between c. 0.01 (below $50 \mathrm{~m} \mathrm{depth}$ ) and 0.3 (the most productive layer, between 20-35 m) $\mu \mathrm{g} \mathrm{C} \mathrm{m}{ }^{-2} \mathrm{~h}^{-1}$. Release of EOC, previously fixed by photosynthesis, was highly variable, ranging between 5 and $80 \%$ of total fixation (particulate + dissolved). Bacterial uptake of the released EOC ranged between 1-20\% of total fixation. Bacterial activities were, in absolute numbers, very low: they ranged between $0.004-0.011 \mu \mathrm{g} \mathrm{C} \mathrm{m}^{-2} \mathrm{~h}^{-1}$. This contrasts with the higher grazing rates on bacteria of $0.007-0.070$ $\mu \mathrm{g} \mathrm{C} \mathrm{m}^{-2} \mathrm{~h}^{-1}$, which should be considered only as maximum or potential rates.

Respiration and diffusion of $\mathrm{CO}_{2}$ to the atmosphere seem to be the main processes controlling DIC concentration. Despite the relative inaccuracy at their estimation, the results showed that they are of a similar magnitude, and clearly higher than photosynthesis and inflow to the lake. DOC and POC concentrations were highly correlated, and their fluxes presented large fluctuations. None of the measured biological activities affecting the DOC could account for these changes. The high inputs of DOC would then be partly due to diffusion from sediments and, probably more significantly, to inputs from the catchment. Decreases in DOC seem to be due to processes leading to a final oxidation to DIC and subsequent release to the atmosphere, since C accumulation in sediments was low, and a large part of respired $\mathrm{C}$ could not be accounted for by the photosynthetically fixed $\mathrm{C}$, but rather must have an allochthonous origin.

Lake Redó seems to act, in general terms, as an heterotrophic system: respiration is higher than photosynthesis, with the budget being balanced by the import of DOC and, to a lesser extent, POC, while most of the carbon seems to be released into the atmosphere. The estimates of diffusive fluxes agreed with this hypothesis. At this stage, the comparison of biogeochemical budgets with biological activity measurements only serves as a rough estimate of the main pathways in the $\mathrm{C}$ cycling in the lake, and as an indication of the issues that need further research in order to obtain an accurate C budget.

- The planktonic food web activities considered here (photosynthesis, release of EOC by phytoplankton, bacterial incorporation) had a minor influence on the $\mathrm{C}$ cycle. Instead, other processes (zooplankton uptake of DOC, bacterial respiration) occurring in the water column, together with some abiotic mechanisms (UV photoxidation, DOC aggregation) may be responsible for the largely unexplained DOC dynamics. 
- More precise measurements of $\mathrm{CO}_{2}$ diffusion are required, while respiration in the water column and in the sediments needs to be more accurately determined, since they seem to constitute the main pathways for $\mathrm{C}$ out of the system.

- Inputs of DOC by diffusion from sediments and, more interestingly, from the catchment have to be measured to evaluate the external $\mathrm{C}$ loading.

- Better estimates of sedimentary fluxes, including resuspension and focussing, and more detailed $\mathrm{C}$ inventories in sediments are needed to assess the role of sediments as a carbon store.

\section{ACKNOWLEDGMENTS}

This study was supported by the EU projects MICOR (EV5V-CT94-0512) and MOLAR (ENV4CT95-007). We acknowledge T. Buchaca, J. Piera and S. Pla for assistance in the field, and R. Franco for analytical work.

\section{REFERENCES}

Alldredge, A.L. \& G.A. Jackson (Eds). 1995. Topical studies in oceanography. Aggregation in marine systems. DeepSea Res. II, 42: 273 pp.

Broecker W. \& T.H. Peng. 1982. Tracers in the sea. LamontDoherty Geological Observatory. New York: 690 pp.

Bushaw, K.L., R.G. Zepp, M.A. Tarr, D. Schulz-Jander, R.A. Bourbonniere, R.E. Hodson, W.L. Miller, D.A. Bronk. \& M.A. Moran. 1996. Photochemical release of biologically available nitrogen from aquatic dissolved organic matter. Nature, 381: 404-407.

Catalan, J. 1988. Physical properties of the environment relevant to the pelagic ecosystem of a deep high-mountain lake (Estany Redó, Central Pyrenees). Oecologia aquatica, 9: 89-123.

Catalan, J. 1989. The winter cover of a high-mountain mediterranean lake (Estany Redó, Pyrenees). Water Res. Res., 25: 519-527.

Catalan, J. 1992. Evolution of dissolved and particulate matter during the ice-covered period in a deep, high mountain lake. Can. J. Fish. aquat. Sci., 49: 945-955.

Catalan, J. \& L. Camarero. 1991. Ergoclines and biological processes in high mountain lakes: similarities between summer stratification and the ice-forming periods in Lake Redó (Pyrenees). Verh. int.Ver. Limnol., 24: 1011-1015.

Catalan, J. \& L. Camarero. 1993. Seasonal changes in alkalinity and $\mathrm{pH}$ in two Pyrenean lakes of very different water residence time. Verh. int. Ver. Limnol., 25: 749-753.

Downing, J.A. \& F.H. Rigler. 1984. A manual on methods for the Assessment of Secondary Productivity in Fresh Waters. Blackwell Scientific Publications. Oxford: 501 pp.

Fee, E.J. 1990. Computer programs for calculating in situ phytoplankton photosynthesis. Can. Tech. Rep. Fish. aquat. Sci., 1740: v+27 pp.

Felip, M., F. Bartumeus, S. Halac \& J. Catalan. 1999. Microbial plankton assemblages, composition and biomass, during two ice-free periods in a deep high-mountain lake (Estany Redó, Pyrenees). In: Straškrabová, V., C. Callieri \& J Fott (Eds), Pelagic food web in mountain lakes. MOuntain LAkes Research Program. J. Limnol., 58(2): 193-202.

Granéli, W., M. Lindell \& L. Tranvik. 1996. Photo-oxidative production of dissolved inorganic carbon in lakes of different humic content. Limnol. Oceanogr., 41: 698-706.

Håkanson, L. 1981. A manual of lake morphometry. SpringerVerlag. Berlin: $78 \mathrm{pp}$.

Holen, D.A. \& M.E. Boraas. 1995. Mixotrophy in chrysophytes. In: Sandgren, C.D., J.P. Smol \& J. Kristiansen (Eds), Chrysophyte algae, ecology, phylogeny and development. University Press. Cambridge.

Jumars, P.A, D.L. Penry, J.A. Baross, M.J. Perry \& B.W. Frost. 1989. Closing the microbial loop: Dissolved carbon pathway by heterotrophic bacteria from incomplete ingestion, digestion and absortion. Deep Sea Res., 36: 483-495.

Kirchman, D.L. 1993. Leucine incorporation as a measure of biomass production by heterotrophic bacteria. In: Kemp, P.F., B.F. Sherr, E.B. Sherr \& J.J. Cole (Eds), Handbook of Methods in Aquatic Microbial Ecology. Lewis Publishers. Boca Raton: 509-512.

Lampert, W. 1978. Release of dissolved organic carbon by grazing zooplankton. Limnol. Oceanogr., 23: 831-834

Platt, T. \& C.L. Gallegos. 1980. Modelling primary production. Plenum Press, New York.

Porter, K.G. \& Y.S. Feig. 1980. The use of DAPI for identifying and counting aquatic microflora. Limnol. Oceanogr., 25: 943-948.

Sherr, E.B. \& B.F Sherr. 1993. Preservation and storage of samples for enumeration of heterotrophic protists. In: Kemp, P.F, B.F. Sherr, E.B. Sherr \& J.J Cole (Eds), Handbook of Methods in Aquatic Microbial Ecology. Lewis Publishers. Boca Raton: 207-212.

Sibbald, M.J. \& L.J. Albright. 1991. The influence of light and nutrients on phagotrophy by the myxotrophic nanoflagellate Ochromonas sp. Mar. Micr. Food Webs, 5: 39-47.

Simon, M. \& F. Azam. 1989. Protein content and protein synthesis rates of planktonic marine bacteria. Mar. Ecol. Prog. Ser., 51: 201-213.

Straškrabová, V., C. Callieri, P. Carrillo, L. Cruz-Pizarro, J. Fott, P. Hartman, M. Macek, J.M. Medina-Sánchez, J. Nedoma \& K. Simek. 1999. Investigations on pelagic food webs in mountain lakes - aims and methods. In: Straškrabová, V., C. Callieri \& J Fott (Eds), Pelagic food web in mountain lakes. MOuntain LAkes Research Program. J. Limnol., 58(2): 77-87.

Strom, S.L., R. Benner, S. Ziegler \& M.J. Dagg. 1997. Planktonic grazers are a potentially important source of marine dissolved organic carbon. Limnol. Oceanogr., 42: 13641374.

Stumm, W. \& J.J. Morgan. 1981. Aquatic Chemistry. Wiley. New York: $780 \mathrm{pp}$.

Ventura, M., L. Camarero, T. Buchaca, D. Livingstone \& J. Catalan. (1999). Recent interannual variability in a deep mountain lake (Redó, Pyrenees): 1. Water column seasonality. J. Limnol.: (submitted).

Wathne, B.M. \& H.E. Hansen (Eds). 1997. MOLAR Project Manual. NIVA report no. 0-96061. NIVA. Oslo: 176 pp. 